\title{
The Impact of COVID-19 on Worldwide Economics
}

\author{
Yude $\mathrm{Wu}^{1, *}$ \\ ${ }^{1}$ School of RDFZ Chaoyang Branch School, Beijing, China \\ "Corresponding author. Email: wuyude@rdfzcygj.cn
}

\begin{abstract}
2019 Corona Virus (COVID-19) is a wide spread disease sweeping the world. It generates the impact on both the macroeconomics and microeconomics as well. From the macroeconomic and microeconomics perspective, the economic and social disruption caused by the pandemic has been devastating, on which a lot of relevant scholars are doing related research. There are many people (especially scientists and public officials) learned a lesson and working on the possible solution because of the serious event. Based on this, this paper hopes to explore the significant impact of COVID-19 on the global economy, in order to offer suggestions for relevant practitioners and researchers to learn from the experience. This paper mainly focuses on the discussion about the impact of GDP (Gross domestic product), industry, long term effect, and direct and indirect uncertainty. The situation of specific countries, especially China in these aspects will be discussed in this paper. These results shed light for simple and powerful administrative possible solution.
\end{abstract}

Keywords: COVID-19, macroeconomic and microeconomic impact, administrative solution

\section{INTRODUCTION}

2019 Corona Virus (COVID-19) is a wide spread disease sweeping the world. It causes a huge loss of life around the world, posing unprecedented challenges to public health, food systems and the work of the world etc. The entire food system of human society is extremely vulnerable to COVID-19. Disruption in food supply chains also affects access to healthy, safe and diverse foods for people around the world [1]. Meanwhile, UNESCO states that the COVID-19 has had a serious impact on education. Due to quarantine and lockdown policies, the physical effects of disease and the fear of mental health, school-age children are often unable to receive education as they would in normal times [2]. There are 160,450,504 confirmed human cases and $3,331,258$ deaths worldwide [3], which is highly lethal and susceptible to infection. The main route of transmission is via respiratory droplets and close contact [4]. Since COVID-19 is a highly contagious disease, an important way to control COVID-19 is to reduce human communication and aggregation. As a result, in order to achieve COVID-19 containment on a global scale, various degrees of blockade and isolation have been carried out. It brings about the stagnation of economic activities and production activities, and has a significant impact on the economy [5]. The economic and social disruption caused by the pandemic has been devastating: tens of millions of people are at risk of falling into abject poverty, while the number of undernourished people is currently estimated to be close to 690 million and could rise by as much as 132 million by the end of the year [6]. Against this unsettling backdrop, China looks much better. Due to strict lockdown policies and improved vaccination coverage, no more than 15-20 new coronavirus cases are registered in China every day, and most of them are imported cases. Compared to some other countries in the world, including India and the United States, China's economy is now almost back to normal. The United States has the highest number of COVID-19 deaths in the world, and this has taken an economic toll on all sectors of society. Employment and income for the bottom quarter of the population fell by $30 \%$.

The COVID-19 outbreak has had a huge impact on economies and societies around the world. Since the disease has spread to almost every corner of the world and has an indelible impact on the global scale. So far, COVID-19 is still not fully under control, its impact on the global economy will be long term. This makes it necessary to keep an eye on the impact [7]. This paper discusses the economic impact of COVID-19 worldwide and take some specific country as the example to illustrate. China's response to the epidemics has been wonderful. So far, actions have been taken including but not limited to nationwide actions and online education 
regarding special procedures of airway management, oxygen therapy, ventilation support, hemodynamic management, sedation, and analgesia. As the epidemic situation has lasted for months, special platforms have also been set up to provide free mental health care to all anesthesia providers participating in acute and critical caring for COVID-19 patients [4]. Although the number of infected cases decreases day by day, the severe negative impact,like unemployment and low GDP (Gross domestic product), to the world economy can't be solved in a short time. Therefore, government should figure out the negative impact and try to motivate the economy by using some expansionary policies. COVID-19 may have some positive impacts on the economy as well. The article discusses about the positive and negative impact of COVID-19 on Chinese economy and proposes some possible solutions.

\section{THE IMPACT OF COVID-19 ON CHINESE ECONOMY}

\subsection{GDP (Gross domestic product)}

The COVID negatively more or less affected the world GDP. GDP is the total output produced in a country during a given period of time, which could directly reflect economic growth and economic recession. During COVID-19, the world GDP fell as Figure 1 shows.

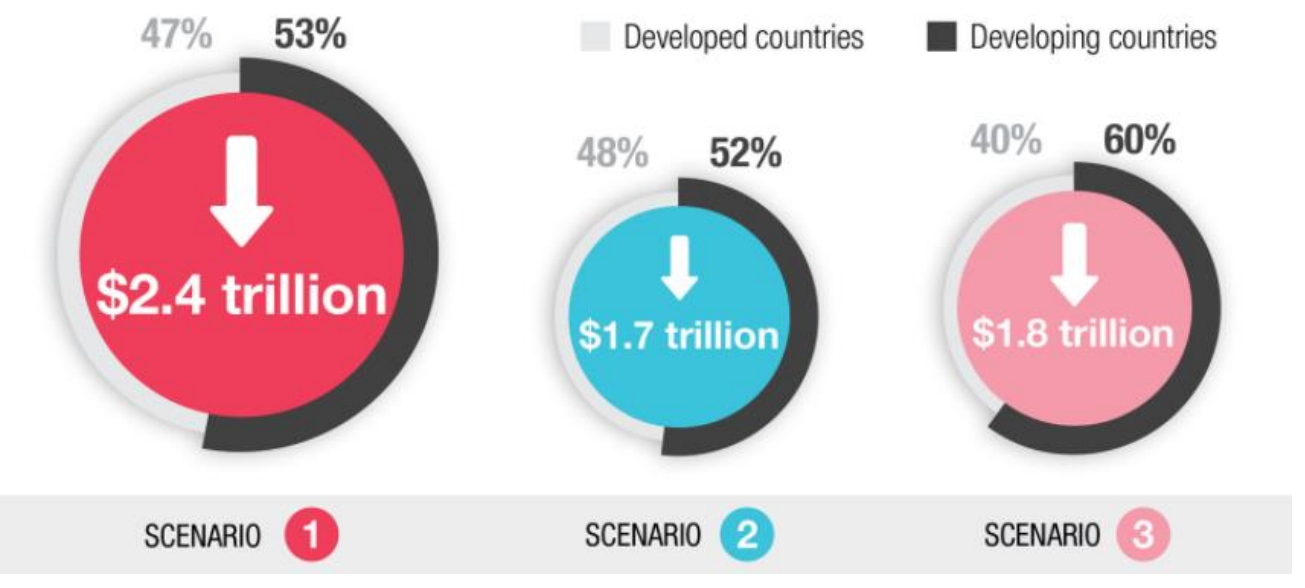

Figure 1. As tourism falls world GDP takes a hit in 2021 (3 alternative scenarios) [8]

Specifically, take China as an example, from the fourth quarter of 2019 to the first quarter of 2020, China's GDP dropped directly from 2780 billion yuan to 9310 billion yuan. The three major industries suffered severe losses, among which the secondary industry showed the largest difference, decreasing from the original 1.092 trillion yuan to 0.904 billion yuan (collected from National Data Network) [9]. The significant decrease reveals the serious economic recession caused by the sudden disease. Risk certainty is a key driving force supporting economic activity. Unknown risks or uncertainty about the future will greatly reduce economic activity. From the perspective of the practice of economic activities, the economic subject can participate in economic activities more and more effectively only when the risk is basically known and the probability is determined. However, the rapid spread of novel coronavirus since its appearance has brought great uncertainty to the economy and society, which led to great impact on the economic production activities [10]. This decrease in GDP is mainly attributed to severe respiratory infectious disease of COVID-19. Nowadays, the most direct way to deal with COVID-19 is social isolation [7], which will also in turn results in the decline of GDP. Economic blockade makes production and life at a standstill, enterprises are difficult to maintain normal operation and appear bankruptcy phenomenon, i.e., the number of unemployed people also surge. The outbreak has mainly affected the supply of labor, an important factor of production [11]. Due to the traffic closure, the transportation of raw materials needed by enterprises for production is hindered, which will greatly affect the cooperation of a large number of industries in the upstream and downstream of the industrial chain. Consequently, it results in the failure to optimize the production plan and resulting in the loss of production efficiency [12]. Meanwhile, the spread of the epidemic and the resulting panic will force people to reduce travel and parties in terms of demand. Besides, local governments will implement closed management in order to prevent and control the epidemic [11]. The combination of the above situation is bound to significantly suppress the demand for transportation, commercial trade, leisure services and other services [2]. Not only would many businesses fail, but individuals and families would face economic hardship. While those who were able to work from home and had higher incomes were able to work normally during the pandemic, many others were unable to work or had their hours drastically reduced [13]. 


\subsection{Industrial change}

Inevitably, COVID-19 has negative and huge impact on traditional industries like restaurant, while the infant industries like Internet services and healthcare grows quickly with huge potential [14]. In a macroeconomic viewpoint, COVID-19 has serious negative impact on the whole economy like lower aggregate demand caused by lowering consumption, lowering investment and lowering exports. In a microeconomic viewpoint, the sudden change of demand and supply, individual consumption willingness and the contraction of aggregate demand will inevitably have an impact on the relevant industries, industrial management and investment plans in the middle level. Thus, it ultimately affects the adjustment and response at the macro level. During the 7-day Spring Festival holiday, the retail sales of catering industry lost about 500 billion yuan. During the epidemic period, $78 \%$ of catering enterprises lost more than $100 \%$ of their business revenue, $9 \%$ of them lost more than $90 \%$ of their revenue, $7 \%$ of them lost between $70 \%$ and $90 \%$ of their revenue, and only $5 \%$ of them lost less than $70 \%$ of their revenue [15].

However, COVID-19 bring an important chance for the development of digital economics and health care system. Additionally, COVID-19 shows the strength of the Chinese government and Chinese political system like the efficient operation and quick execution. Ecommerce is growing strongly in all regions, with consumers in emerging economies making the biggest shift to online shopping, according to the report. For example, Mercado Libre, an online marketplace in Latin America, saw daily sales double in the second quarter of 2020 compared with the same period last year. Jumia, an African e-commerce platform, reported a $50 \%$ increase in transactions in the first six months of 2020 [16]. In March 2020, the number of shopping app downloads in Thailand increased by $60 \%$ in just one week. The International Educational Technology Association has a website called "Learning Keeps Going" for teachers, students, and parents. Germany is using the "MEBIS" education portal to provide information on multimedia resources, exam materials, learning platforms, online learning tools, etc. In the UK, primary and secondary school students are taking the initiative to learn online through platforms such as Zoom, and have set up a website similar to "Learning Keeps Going" in collaboration with academics in the United States [1].

From the whole world's development's perspective, the world's development stagnates a lot. For example, the growth rate of each economic party decreases a lot, the unemployment rate increases dramatically. Between January 2020 and July 2020, the U.S. unemployment rate rose from $3.6 \%$ to $10.1 \%$, industrial production fell by $9 \%$, and non-farm payrolls fell by 12.5 million [17]. In the United States, workers who have lost their jobs or reduced hours due to the outbreak can also apply for unemployment insurance if they work part-time. Including government-sponsored self-employed workers, gig workers and other programs that do not qualify for formal state unemployment programs, 1.14 million people filed claims last week. At least 20.5 million people were receiving unemployment benefits in early November. At least 15.33 million Indians were unemployed in May, according to the Centre for Economic Monitoring of India (CMIE), a figure that exceeds all job growth in India since July 2020. In April 127 million people were employed in small business and daily wage jobs, but that number fell to 110 million in May. From December to March, things picked up [2].

Faced with this series of economic downturn, the Federal Reserve and the federal and state governments have taken a series of measures to deal with the virus crisis [18]. The viral crisis caused panic, with investors aggressively selling US equities and moving into safe haven assets, e.g., long-term Treasury bonds and gold [19]. The frequency and the scale of international trade unstably shrank a lot, the price of dollar in the foreign exchange market depreciated and the size of foreignowned national debt of each country surged [17]. COVID-19 brought a series of industrial structural changing and both side economic impacts.

\subsection{Long term effect}

COVID-19, in negative terms, may limit the economy's long-term growth and bring about a decline in revenue, if uncontrolled or not delayed. Major public emergencies can cause lasting and irreparable damage like slow globalization. According to the latest International Monetary Fund (IMF) growth projections, 33 developing countries will still have lower income per capita than their 2019 levels [20]. Research institutes estimate that in January 2020, only 4.3 per cent of Indians lived on less than $\$ 2$ a day [14]. A year later, that number rose to 9.7 per cent, or 134 million people. After last year's nationwide blockade, $230 \mathrm{~m}$ people in India fell below the national poverty line. The researchers found that 90 percent of the poor consumed less food during the blockade [10]. Six months later, they still hadn't returned to their normal diet. Wages in India have fallen by a third in the past year [3]. In terms of health care, the COVID19 outbreak has posed a significant challenge to the care of SDB patients. Columbia University research indicates that social distance and limited access to contraceptive and abortion care during the COVID-19 pandemic are affecting the sexual and reproductive health of adolescents and young adults. In terms of health care, the COVID-19 outbreak has posed a significant challenge to the care of SDB patients [18]. Columbia University research shows that social distance and limited access to contraceptive and abortion care during the COVID-19 pandemic are affecting the sexual and reproductive health of adolescents and young adults. In terms of social 
distance, people have gradually formed the habit of maintaining a certain interpersonal distance due to the fact that maintaining social distance can contain the COVID-19 pandemic with sufficient reasons [17]. Global residents have maintained more than one meter of social distance from the end of 2019 to now. The COVID-19 pandemic has accelerated the global trend of reading news stories on social media, but it has also led to the alienation of relationships in real life. In terms of vaccine development, Imperial College London said the vaccine could boost the immune response of those who still have the virus lurking in their bodies, leading to the virus being eliminated. In the future, COVID-19 vaccine research will be a long-term process [3].

Nevertheless, it also has a positive side to investment in human resources and technology. Some catastrophic events spur investment in human capital and the adoption of new technologies. Greater industrialisation may be a direct consequence of higher incomes. An environment of labor shortages, high labor income and per capita wealth creation by the Justinian Plague from the sixth to the eighth centuries created an overlap of regional political and structural changes in the Islamic Golden Age from the eighth to the tenth centuries, which has a "ratchet effect" on wages [19]. The emergency achieved permanent growth and created the conditions for the birth of the industrial revolution in the UK [10].

\section{DIRECT AND INDIRECT UNCERTAINTY}

Although there are advanced technology and health care services in the modern society, the death rate of COVID-19 is even higher than Ibola virus and H1N1 virus. The wide spread of the virus arouses the psychological fear of disease in human beings. Under the fast globalization, the interaction between different countries is becoming more and more frequently. In the case of combination of factors, the uncertainty and fear of disease are exaggerated and as a result of huge contraction of economic activity. There are two main uncertainties caused by COVID-19. The first one is that the rate of the spreading of virus is too fast to control, which has greatly tested the government's ability to respond to a major public health event. On the other hand, the sudden impact on economics is a huge challenge for traditional government intervention. Under a gloomy global economic environment, the economic chain is broken and economic activities are suspended. Since the government spends only $1.2 \%$ of GDP on health care, Indians spend around $60 \%$ of their own money on health care in normal times [3]. In previous years, one in 20 families fell back into poverty because of health care costs. Indians are forced to sell their gold, possessions and borrow money from usury to pay for their treatment [3].

\section{CONCLUSION \& SUGGESTION}

In summary, the government has to review and improve the policy from the perspective of industrial structure and the way of managing after controlling the situation. The policy could take into account the actual national conditions and the implementation of epidemic prevention measures. According to the long-term positive trend of Chinese mixed economy, simple and powerful administrative power is the most directly effective solution. However, because of the huge pressure or severe competition in each industry, government have to use moderate macroeconomic policy carefully like controlling the intensity of quantitative easing. Government could focus on supporting specific industries, e.g., decreasing taxes within some target industries and injecting some intervention. These results offer a guideline for simple and powerful administrative possible solution.

\section{REFERENCES}

[1] B. Ashraf, Journal of behavioral and experimental finance, Economic impact of government interventions during the COVID-19 pandemic: International evidence from financial markets. (2020)

[2] E. Denis, O. Telle, S. Benkimoun, The Conversation., Mapping the lockdown effects in India: how geographers can contribute to tackle Covid-19 diffusion. (2020)

[3] S. Maital, E. Barzani, Samuel Neaman Institute for National Policy Research, The global economic impact of COVID-19: A summary of research. (2020)

[4] H. Zhang, L. Bo, Y. Lin, F. Li, Anesthesiology, Response of Chinese anesthesiologists to the COVID-19 outbreak. (2020)

[5] J. Ataguba, COVID-19 pandemic, a war to be won: understanding its economic implications for Africa. (2020)

[6] R. Andrson, H. Heesterbeek, D. Klikenberg. The lancet, How will country-based mitigation measures influence the course of the COVID-19 epidemic? (2020)

[7] M. Buheji, K. Costa ..., American Journal of Economics, The extent of covid-19 pandemic socioeconomic impact on global poverty. a global integrative multidisciplinary review. (2020)

[8] Information from: https://unctad.org/news/globaleconomy-could-lose-over-4-trillion-due-covid-19impact-tourism 
[9] L. Zhao, Influences of COVID-19 on China's economy and industries. (2020)

[10] X. He, H. Wang, C. Jiao, Influences of COVID-19 on the global economy and countermeasures in China. (2020)

[11] A. Martin, M. Markhvida, S. Hallegatte, B. Walsh, Economics of disasters and climate change, Socioeconomic impacts of COVID-19 on household consumption and poverty. (2020)

[12] H. Gopalan, A. Misra, Diabetes \& Metabolic Syndrome: Clinical Research \& Reviews. COVID19 pandemic and challenges for socio-economic issues, healthcare and national programs in India. (2020)

[13] J. Han, B. Meyer, J. Sullivan, Income and Poverty in the COVID-19 Pandemic (No. w27729). National Bureau of Economic Research. (2020)

[14] D. Zhao, B. Wan, J. Zheng, Y. Wang, Study on the impact characteristics and industry differences of COVID-19. (2020)

[15] X. He, H. Wang, C. Jiao, Influences of COVID-19 on the global economy and countermeasures in China. (2020)

[16] Y. Zhang, COVID-19 and the world economic situation. (2020)

[17] B.Singh, SSRN 3609973, Impact of COVID-19 on rural economy in India. (2020)

[18] S. Sengupta, M. Jha, The International Journal of Community and Social Development, Social policy, COVID-19 and impoverished migrants: challenges and prospects in locked down India. (2020)

[19] A. Wright, K. Sonin, Journal of Economic Behavior \& Organization, Poverty and economic dislocation reduce compliance with covid-19 shelter-in-place protocols. (2020)

[20] J. Qi, The major impact of COVID-19 on the world. (2020) 